\title{
Efficiency of lighting for lecture halls
}

\author{
Eficientizarea iluminatului în amfiteatre
}

\section{${ }^{1}$ Sergiu Fodorean}

Facultatea de Inginerie a Instalatiilor, Universitatea Tehnica din Cluj - Napoca, Romania Bulevadrul 21 Decembrie 1989, no. 128 - 130

E-mail: sfodorean@gmail.com

\section{${ }^{2}$ Dorin Beu}

Facultatea de Inginerie a Instalatiilor, Universitatea Tehnica din Cluj - Napoca, Romania Bulevadrul 21 Decembrie 1989, no. 128 - 130

E-mail:dorin.beu@rogbc.org

\section{${ }^{3}$ Calin Ciugudeanu}

Facultatea de Inginerie a Instalatiilor, Universitatea Tehnica din Cluj - Napoca, Romania Bulevadrul 21 Decembrie 1989, no. 128 - 130

E-mail: calin.ciugudeanu@insta.utcluj.ro

DOI: $10.37789 /$ rjce.2022.13.1.10

\begin{abstract}
Fluorescent tubes as well as LEDs have advantages and disadvantages, but it seems that the LED is starting to come out a winner in the attention of consumers.

In this paper we present the advantages that are offered to us by using LED luminaires. WE do this by comparison between, three types of luminaire, $2 \times 1836 \mathrm{~W}$ fluorescent luminaire, 2xT5 28W electronic ballast luminaire and 36W LED luminaire.

The measurements were made with new fluorescent lamps but also with fluorecent lamps that have already been used for a period (approx. 4800 hours). The LED luminaire used for the measurements were used for almost 1300 hours. We compared the measurements made with LED luminaire with the results obtained from measurements of the fluorescent lamps.In both cases even if I used old or new fluorescent luminaires, the results were in favor of LEDs, with a much higher energy efficency.
\end{abstract}

Key words: LED, fluorescent luminaire, energy efficient, lighting, measurements

\section{Introduction}

Fluorescent luminaires have been used and been around us for years. It has been proven over time that they are economical and produce optimal light for workspace and public environments. However, a new method of lighting has attracted attention: LED. [1] 
The principle of operation of fluorescent lamp remains the same as that of all conventional discharge lamps: mercury atoms are excited to the point where they irradiate ultraviolet light as they return to a low energy level. This ultraviolet light is transformed into visible light as it passes through the fluorescent tube.

Two other essential components in the operation of fluorescent lamps are the starter and the ballast. When supplied with electricity, the starter allows the electrodes to be brought to the incandescent and then the heating current to be switched off after the lamp has been switched on. The ballast provides and overvoltage at the tube terminals, which is necessary to prime the electric arc in the gas mixture inside and subsequently limits the current through the tube, while allowing its stable operation.[2]

An LED lamp consists of one or more light emitting diodes (LEDs). LED lamps have much longer lifespan and energy efficiency than incandescent or fluorescent lamps, these lamps can reach up to 100000 operating hours and can emit up to 200 lumens per watt, while fluorescent lamps have an efficient up to 100 lumens per watt. [1]

The LED is made of a semiconductor anorganic material. This material is found under solid state in nature, thus making the LED more durable and resilient. When electric current passes through this semiconductor material, the electrons in the material access higher energy levels and begin to emit energy in the form of visible light. [2]

\section{Study case}

To observe the differences between three luminaires (two fluorescent and one LED), we made measurements two situation (in the experimental stand also in the work stand). I measured new and old fluorescent lamp in the experimental stand as well as in the working stand (4200 operating hours). The experimental stand $2 \mathrm{~m} \times 2 \mathrm{~m}$ $\left(1.96 \mathrm{~m}^{2}\right)$ and we used a calculation grid of $40 \mathrm{x} 40 \mathrm{~cm}$, while the work stand is the room I205 (lecture hall of the Faculty of Building Service Engineering $56.13 \mathrm{~m}^{2}$ ), having a calculation grid of $80 \times 60 \mathrm{~cm}$.

We will compare the luminaires with new fluorescent lamps (T5) with the old ones (T8) as well we are going to compare fluorescent lamps T5 with LED luminaires.

3 different types of lightings ( 2 different fluorescent lamps and LED light), but were used with more scenarios: - T8 fluorescent lamp cleaned and dirty

- T5 fluorescent lamps, cleaned and dirty

- LED lighting, cleaned and dirty 
Efficiency of lighting for lecture halls

\section{RESULTS - EXPERIMENTAL STAND}

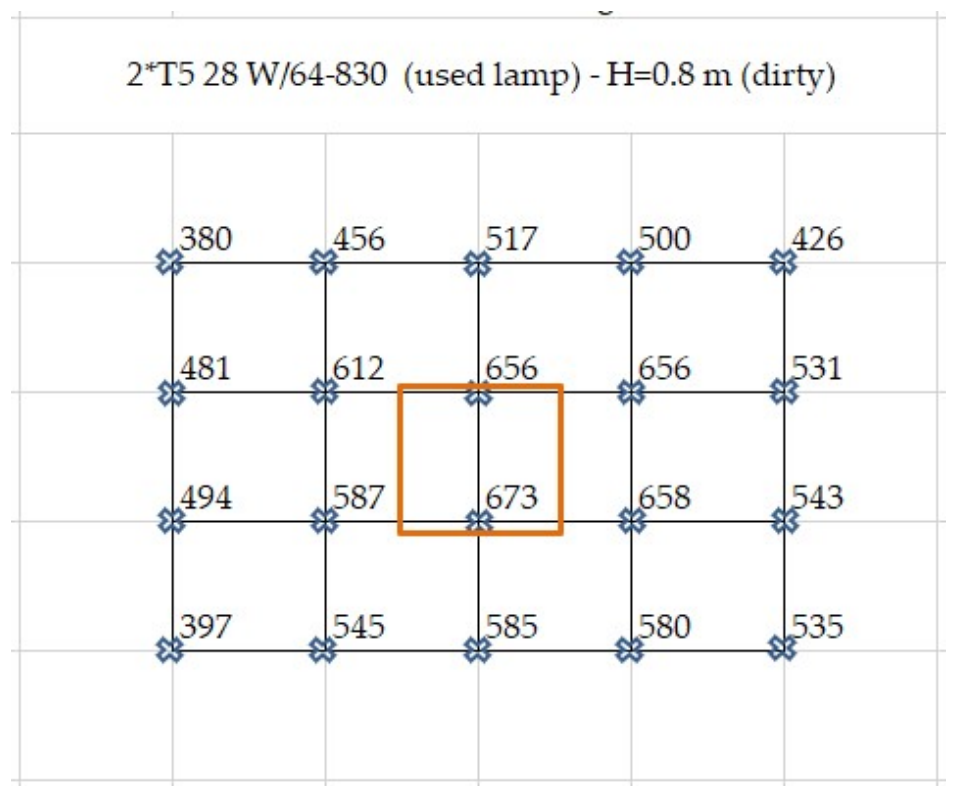

Fig. 1. Measurements 2*T5 (used and dirty lamp).

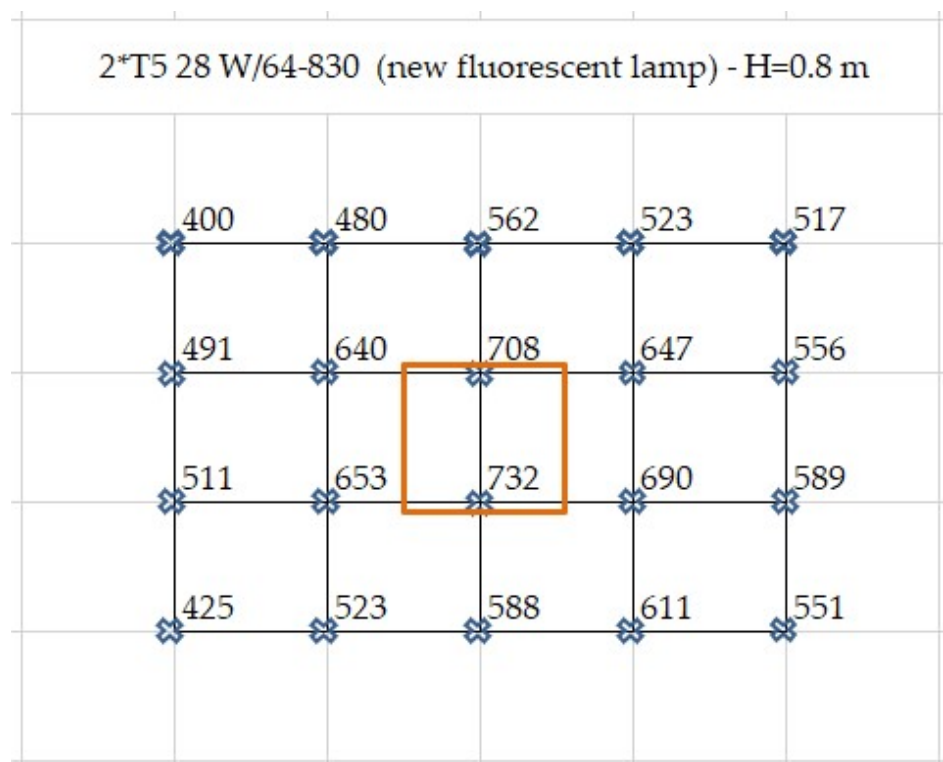

Fig. 2. Measurements $2 * \mathrm{~T} 5$ (new lamp). 
Sergiu FODOREAN, Dorin BEU, Calin CIUGUDEANU

2*T8 $36 \mathrm{~W} / 72-765$ (fluorescent lamp used) - $\mathrm{H}=0.8 \mathrm{~m}$ (dirty)

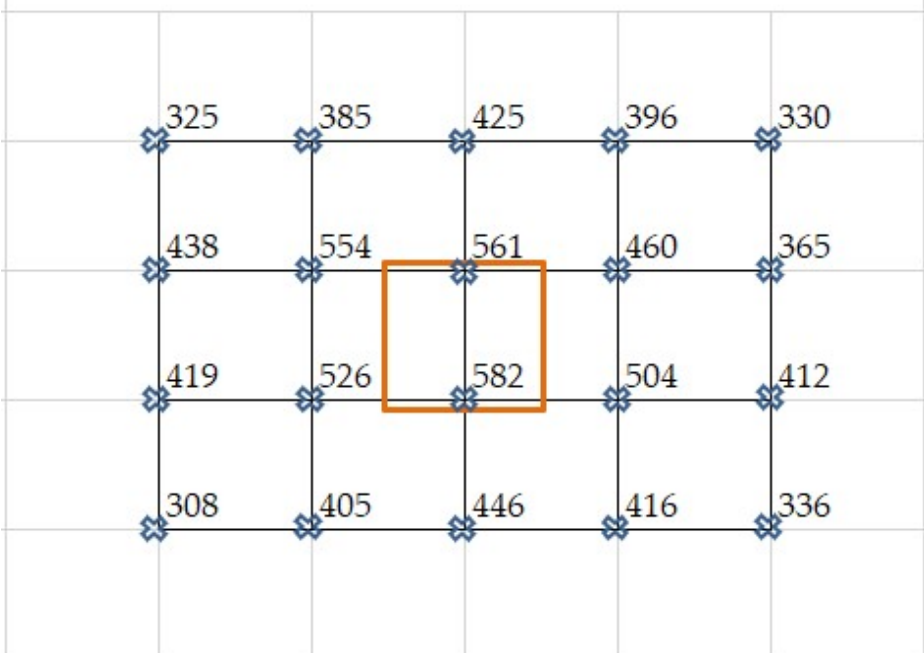

Fig. 3. Measurements 2*T8 (used and dirty lamp).

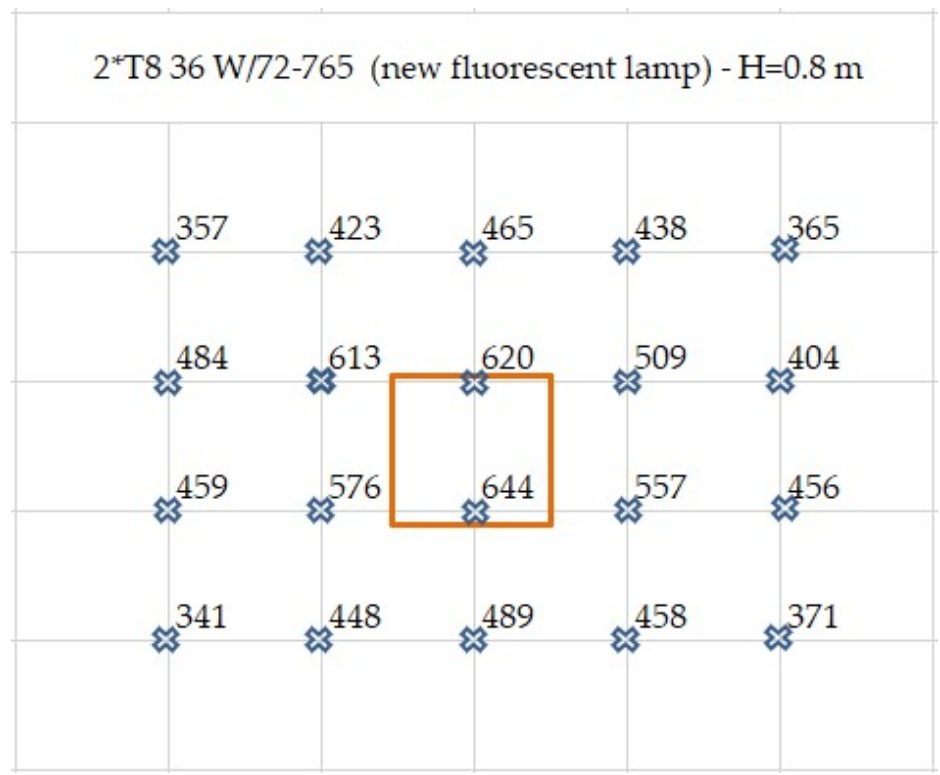

Fig. 4. Measurements $2 * \mathrm{~T} 8$ (new fluorescent lamp). 
Efficiency of lighting for lecture halls

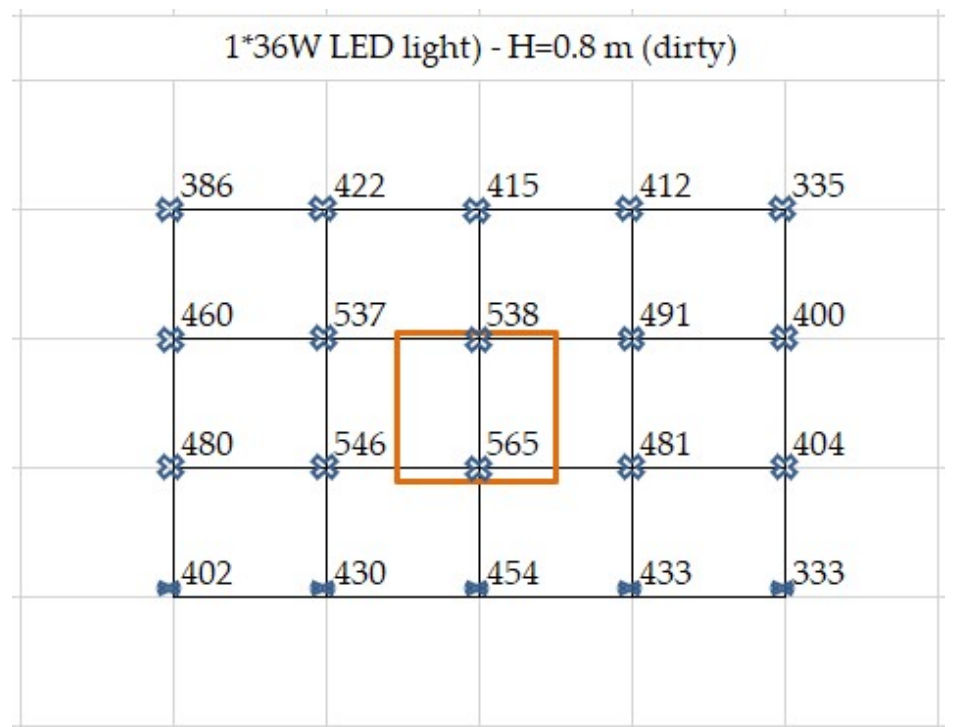

Fig. 5. Measurements LED lighting (used and dirty lamp).

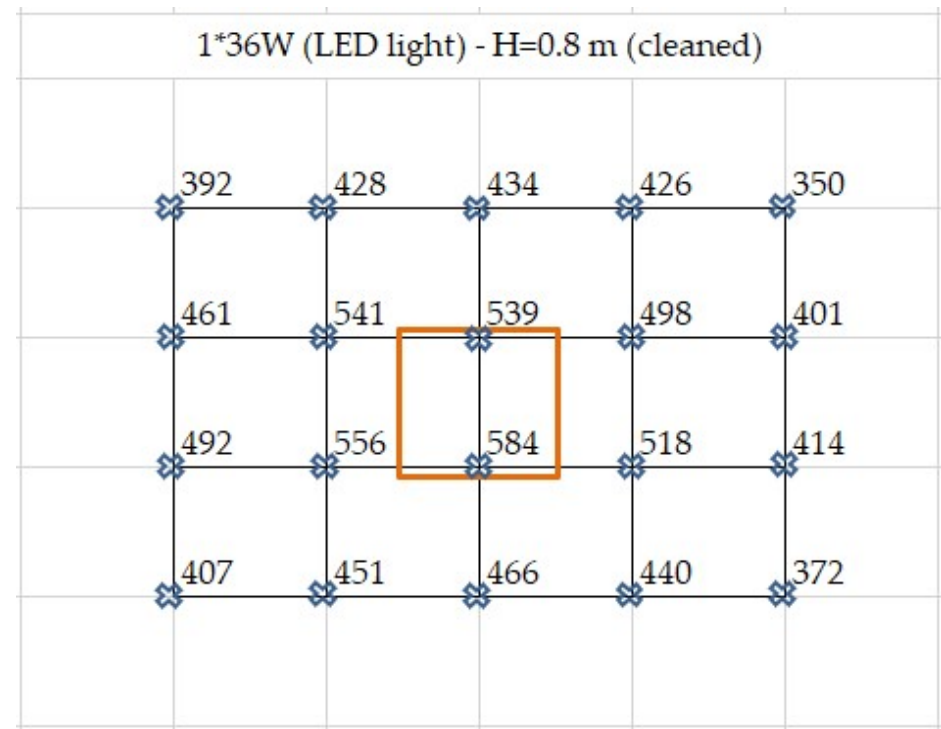

Fig. 6. Measurements LED (used and cleaned lamp). 
Sergiu FODOREAN, Dorin BEU, Calin CIUGUDEANU

\begin{tabular}{|c|c|c|c|c|c|c|}
\hline MEASURED & $\begin{array}{c}\text { 2*T5 } 28 \mathrm{~W} / 64 \\
830 \text { used, } \\
\text { dirty } \\
\text { fluorescent } \\
\text { light }\end{array}$ & $\begin{array}{c}\text { 2*T5 } 28 \\
\text { W/64-830 } \\
\text { new } \\
\text { fluorescen } \\
\text { t light }\end{array}$ & $\begin{array}{c}\text { 2*T8 } 36 \\
\text { W/72-765 } \\
\text { used, dirty } \\
\text { fluorescen } \\
\text { t light }\end{array}$ & \begin{tabular}{|c|}
$2 * T 836$ \\
W/72-765 \\
new \\
fluorescen \\
t light
\end{tabular} & $\begin{array}{c}1^{*} \text { Led } \\
36 \mathrm{~W} \\
\text { dirty } \\
\text { LED light }\end{array}$ & $\begin{array}{c}1^{*} \text { Led } \\
36 \mathrm{~W} \\
\text { cleaned } \\
\text { LED light }\end{array}$ \\
\hline Total power per luminaire [W] & 64 & 64 & 72 & 72 & 36 & 36 \\
\hline Minimum ilumination level [1x] & 380 & 400 & 308 & 341 & 333 & 350 \\
\hline Maximum ilumination level [1x] & 673 & 732 & 582 & 644 & 565 & 584 \\
\hline Average ilumination level [1x] & 541 & 570 & 430 & 474 & 446 & 459 \\
\hline Uniformity [min/average] & 0.70 & 0.70 & 0.72 & 0.72 & 0.75 & 0.76 \\
\hline $\begin{array}{l}\text { Lighting power density } \\
{[\mathrm{W} / \mathrm{sqm} / 1001 \mathrm{x}]-2 * 2.4=4.8 \mathrm{sqm}}\end{array}$ & 2.47 & 2.34 & 3.49 & 3.17 & 1.68 & 1.64 \\
\hline
\end{tabular}

Fig. 7. Results of measurements

It can be observed the difference between these luminaires, based on the measurements on the experimental stand, because each luminaire had the same measuring grid and each measurement was made with the same measuring device (TESTO luxmeter).

We can see the difference between the T8 and T5 ( both of them were used for 4800 hours) and LED light (about 1300 hours of operation), we can observe the consumption per square meter of each luminaire and we see that the LED luminaire has the lowest consumption of $1.64 \mathrm{w} / \mathrm{sqm}$ compared with $\mathrm{T} 8$ that have $3.14 \mathrm{~W} / \mathrm{sqm}$, and $\mathrm{T} 5$ lamp with a consumption of $2.47 \mathrm{~W} / \mathrm{sqm}$.

\section{RESULTS - work stand}

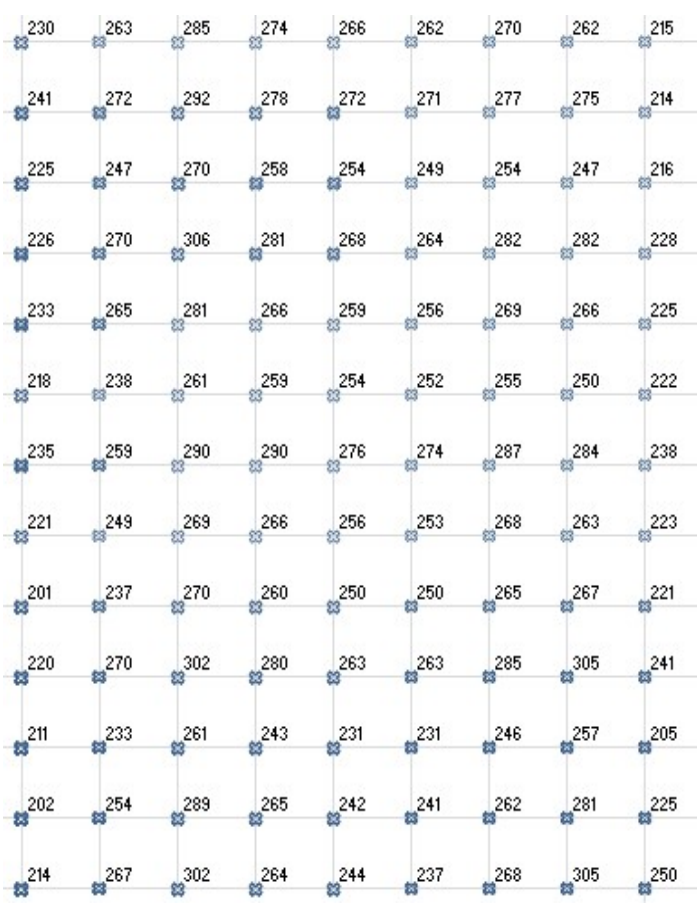

Fig. 8. Measurements in the classroom $2 * \mathrm{~T} 8$ fluorescent luminaire

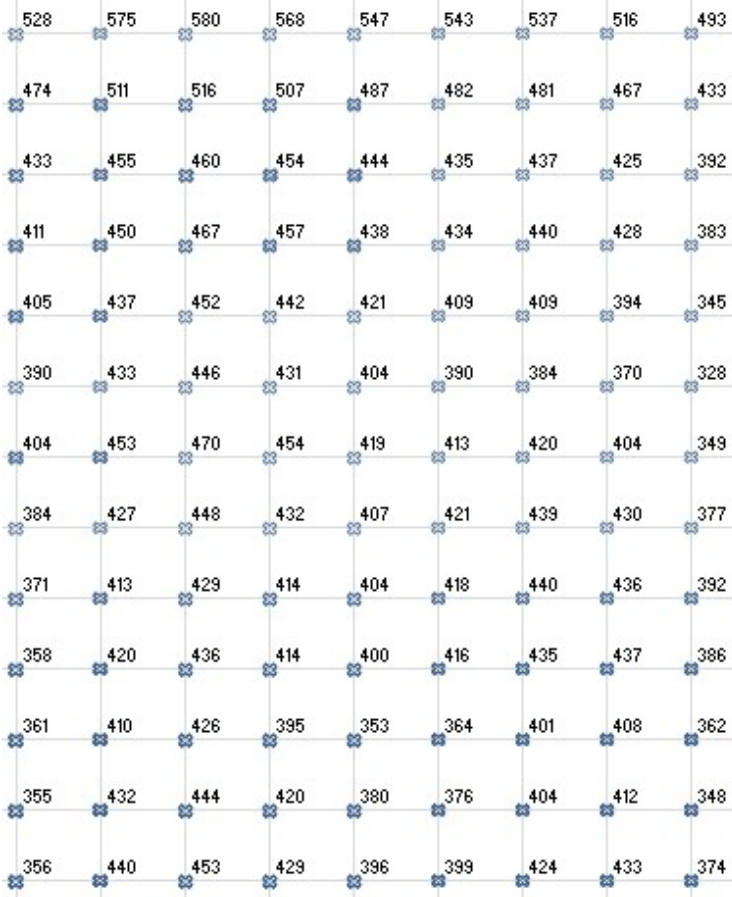

Fig. 9. Measurements in the classroom $2 * \mathrm{~T} 5$ fluorescent luminaire 
Efficiency of lighting for lecture halls

\begin{tabular}{|c|c|c|c|}
\hline MEASURED & $\begin{array}{l}2^{*} \mathrm{~T} 528 \mathrm{~W} / 64- \\
830 \text { new lamp) }\end{array}$ & MEASURED & $\begin{array}{c}\text { 2*T8 } 36 \text { W/72- } \\
765 \text { ( used, dirty } \\
\text { lamp) }\end{array}$ \\
\hline Total power per luminaire [W] & 768 & Total power per luminaire [W] & 864 \\
\hline Minimum ilumination level [1x] & 328 & Minimum ilumination level [1x] & 201 \\
\hline Maximum ilumination level [lx] & 580 & Maximum ilumination level [1x] & 306 \\
\hline Average ilumination level [lx] & 428 & Average ilumination level [lx] & 256 \\
\hline Uniformity [min/average] & 0.77 & Uniformity [min/average] & 0.79 \\
\hline $\begin{array}{l}\text { Lighting power density } \\
{[\mathrm{W} / \mathrm{sqm} / 1001 \mathrm{x}]-6 * 9=54 \mathrm{sqm}}\end{array}$ & 3.32 & $\begin{array}{l}\text { Lighting power density } \\
{[\mathrm{W} / \mathrm{sqm} / 1001 \mathrm{x}]-6 * 9=54 \mathrm{sqm}}\end{array}$ & 6.25 \\
\hline
\end{tabular}

Fig. 10. Result of measurements for new T5

Fig. 11. Result of measurements for used T8

Measurements were made in the working plan (I205 lecture hall from the Faculty of Building Services Engineering), with a calculation grid of $80 \times 60 \mathrm{~cm}$.

The measurements were made with used T8 4800 operating hours) and in new T5 luminaires. In the case of old T8, we have consumption of $6.01 \mathrm{w} / \mathrm{sqm}$ and the lighting level is at half, i.e. on average $250 \mathrm{~lx}$ respectively with $500 \mathrm{~lx}$

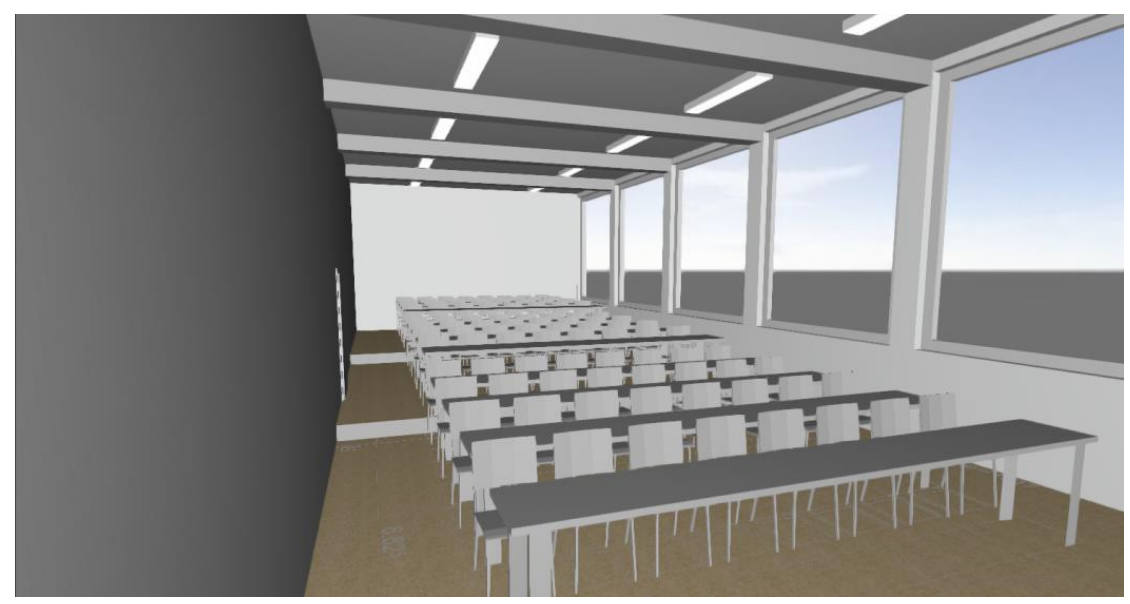

Fig. 12. Representation of lecure hall I205 of the Faculty of Building Services Engineer in Dialux EVO program

\section{Conclusions}

Following the measurements in the experimental stand we can see that the luminaire equipped with LEDs are superior in terms of energy efficiency and lighting.

The energy efficiency of LED luminaires is $43.03 \%$ higher than T5 fluorescent luminaire and 93\% higher than T8 fluorescent luminaires.

If we refer to the Faculty of Installation Engineering with has an area of 4776 sqm we can calculate for each scenario the energy consumption using new lamps. For the T5 lamps we have a consumption of $24.45 \mathrm{~kW}$, for the lamps equipped with T8 a consumption of $37.77 \mathrm{~kW}$, while the LEDs have a consumption of $19.53 \mathrm{~kW}$. 


\section{Bibliography}

[1] Dascalaki Elena G., and Vasileios G. Sermpetzoglou. "Energy Performance and Indoor Environmental Quality in Hellenic Schools." Energy and Buildings, vol. 43, no. 2-3, Feb. 2011, pp. 718-27. DOI.org (Crossref), doi:10.1016/j.enbuild.2010.11.017.

[2] Ciugudeanu, C., Beu, D, Rastei, E., Living Building Laboratory - Educational Building Project in Cluj-Napoca, Conference Sustainable Solutions for Energy and Enviroment, EENVIRO YRC 2015 18-20 november.

[3] Analysis of the EU Residential Energy Consumption: Trends and Determinants. Energies 2019, 12, 1065., Sofia Tsemekidi Tzeiranaki, Paolo Bertoldi, Francesca Diluiso, Luca Castellazzi, Marina Economidou, Nicola Labanca, Tiago Ribeiro Serrenho, Paolo Zangheri,

[4] SR EN 12464-1/2011 Lumina si iluminat. Iluminatul locurilor de munca. Partea 1: Locuri de munca in terioare (Light and lighting. Lighting of workplaces. Part 1: Indoor work places).

[5] Normativ privind proiectarea, executia si exploatarea instalatiilor electrice aferente cladirilor Indicatit I7 - 2011

[6] LEL - Lighting Engineering Laboratory UTC-N. 2013. The Modernization and Expansion of the Public Lighting System and Upgrading Lighting System in Two City Hall Buildings Using LED Technology. Project nr.380333/2013, Cluj-Napoca.

[7] Doulos, L. T., et al. "Minimizing Energy Consumption for Artificial Lighting in a Typical Classroom of a Hellenic Public School Aiming for near Zero Energy Building Using LED DC Luminaires and Daylight Harvesting Systems.” Energy and Buildings, vol. 194, July 2019, pp. 20117. DOI.org (Crossref), doi:10.1016/j.enbuild.2019.04.033.8 